\title{
THE PLATINUM(II) COMPLEXES INDUCED OXIDATIVE STRESS OF ISOLATED RAT HEART
}

\author{
Katarina Radonjic ${ }^{1}$, Isidora Stojic ${ }^{1}$, Vladimir Zivkovic ${ }^{2}$, Ivan Srejovic ${ }^{2}$, Nevena Jeremic ${ }^{1}$, Vladimir Jakovljevic ${ }^{2}$, Dragan Djuric ${ }^{3}$, Slobodan Novokmet ${ }^{1}$ \\ ${ }^{1}$ Department of Pharmacy, Faculty of Medical Sciences, University of Kragujevac, Serbia \\ ${ }^{2}$ Department of Physiology, Faculty of Medical Sciences, University of Kragujevac, Serbia \\ ${ }^{3}$ Institute of Medical Physiology “Richard Burian”, Faculty of Medicine, University of Belgrade, Serbia

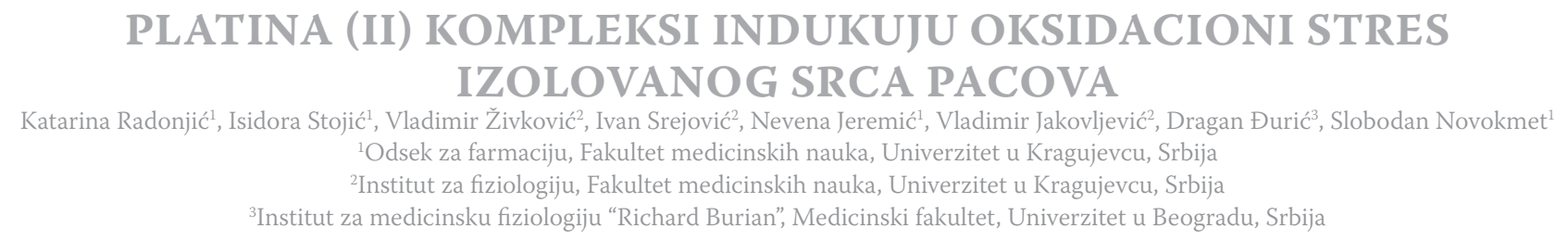

Received / Primljen: 04.07.2016

Accepted / Prihvaćen: 26.07.2016

\begin{abstract}
Interest for the clinical application of transition metal complexes as chemotherapeutic agents initially started with discovery of cisplatin. Despite the remarkable clinical success, cisplatin treatment is limited due to its resistance and side effects. Over the last 40 years, numerous transition metal complexes were synthesized and investigated in vitro and in vivo in order to establish a metallopharmaceutical that will exert less toxicity and equal or higher potency. We have compared the cardiotoxicity of 2 platinum complexes, one ligand, and a starting salt for complex synthesis using an experimental model of an isolated, perfused rat heart according to the Langendorff technique. The cardiotoxicity was assessed by comparison of oxidative stress induced following the perfusion of the following compounds: Dichloro(1,2-diaminocyclohexane)platinum(II), cisplatin, potassium-tetra-chloroplatinum(II) and 1,2-diaminocyclohexane, which were perfused at increasing concentrations from $10^{-8}$ to $10^{-4} \mathrm{M}$ for 30 minutes. The oxidative stress was assessed by determination of superoxide anion radical, hydrogen peroxide, thiobarbituric acid reactive substances, and nitric oxide from the coronary venous effluent. Our results showed that the levels of oxidative stress parameters were not significantly affected by perfusion with all the tested compounds and were not dosedependent. These results could be of importance to further investigations concerning the effects of platinum-based potential anticancer drugs on the heart.
\end{abstract}

Key words: cisplatin, 1,2-diaminocyclohexane, isolated rat heart, oxidative stress, perfusion, platinum(II) complexes

\section{SAŽETAK}

Interesovanje za kliničku primenu kompleksa prelaznih metala kao hemioterapijskih lekova započeto je otkrićem cisplatine. Uprkos izvanrednom kliničkom uspehu, lečenje cisplatinom je ograničeno zbog njene rezistencije $i$ neželjenih efekata. Tokom poslednjih 40 godina sintetisan je veliki broj kompleksa prelaznih metala $i$ ispitan in vitro $i$ in vivo sa ciljem uvođenja metalofarmaceutika koji bi imao manju toksičnost $i$ istu ili veću potentnost. Mi smo poredili kardiotoksičnost dva kompleksa platine, jedan ligand i so potrebnu za početak sinteze kompleksa, koristeći eksperimentalni model izolovanog, perfundovanog srca pacova metodom po Langendorfu. Kardiotoksičnost se procenjivala uporedivanjem oksidacionog stresa indukovanog perfuzijom tih supstanci. Dihloro(1,2-diaminocikloheksan) platina (II), cisplatina, kalijum-tetra-hloroplatinat i 1,2-diaminocikloheksan su primenjeni u rastućim dozama od $10^{-8}$ do $10^{-4} \mathrm{M}$ tokom 30 minuta. Oksidacioni stres je odredivan merenjem superoksid anjon radikala, vodonik peroksida, indeksa lipidne peroksidacije $i$ azot-monoksida u koronarnom venskom efluentu. Naši rezultati su pokazali da nivoi parametara oksidacionog stresa nisu bili značajno povišeni niti dozno-zavisni nakon perfuzije svih ispitivanih supstanci. Ovi rezultati bi mogli biti od značaja za buduća istraživanja potencijalnih antitumorskih lekova zasnovanih na platini u pogledu efekata na srce.

Ključne reči: cisplatina, 1,2-diaminocikloheksan, izolovano srce pacova, oksidacioni stres, perfuzija, kompleksi platine(II)

\section{ABBREVIATIONS}

CDDP - cisplatin GSH - glutathione

DACH - 1,2-diaminocyclohexane

DNA - deoxyribonucleic acid

$\mathrm{H}_{2} \mathrm{O}_{2}$ - hydrogen peroxide

$\mathbf{K}_{2}\left[\mathbf{P t C l}_{4}\right]$ - potassium-tetra-chloroplatinum(II)
mtDNA- mitochondrial deoxyribonucleic acid

NO - nitric oxide

$\mathrm{O}_{2} \cdot-$ - superoxide anion radical

$\mathbf{P t}^{(\mathrm{II})} \mathbf{D A C H C l} \mathbf{H}_{2}$ - dichloro (1,2-diaminocyclohexane)

platinum(II)

ROS - reactive oxygen species

TBARS - Thiobarbituric Acid Reactive Substances 


\section{INTRODUCTION}

Clinical use of metal-based anticancer drugs began in 1970s, several years after the accidental discovery of the antitumour effects of cisplatin (CDDP) by Rosenberg in $1965(1,2)$. Cisplatin is one of the most effective chemotherapeutic agents for the treatment of various cancers, such as lung, bladder, neck, ovarian, and testicular (3). It has a potent cytotoxic effect due to its ability to cross-link DNA through a covalent coordinate bond to the N7 atoms of guanine and adenine. This molecular mechanism prevents replication and transcription of DNA and finally leads to apoptosis and cell death (4). Other targets of cisplatin are glutathione and metallothioneins, to which binding has been associated with the development of resistance and toxicity (5). Accordingly, the clinical use of cisplatin is severely limited, especially by dose-dependent side effects, such as nephro-, oto-, neuro-, hepato-, and cardiotoxicity $(6,7)$. Over the past decades, medicinal chemists have been devoted to the development of a large number of novel platinum complexes with less toxicity and more antitumour success $(8,9)$.

Many preclinical and clinical researchers have suggested that chronic cisplatin therapy is associated with severe side effect such as cardiotoxicity $(10,11)$. Cardiotoxicity may be an early or late complication after treatment with cisplatin. Acute manifestations are accompanied with electrocardiographic changes and arrhythmias, while late complications are primarily associated with the development of cardiomiopathy and congestive heart failure (12-14). Experimental evidence supports the hypothesis that cisplatin and its analogues promote cardiotoxicity through the formation of reactive oxygen species (ROS), such as superoxide anion radical $\left(\mathrm{O}_{2}^{-}\right)$, hydrogen peroxide $\left(\mathrm{H}_{2} \mathrm{O}_{2}\right)$, Thiobarbituric Acid Reactive Substances (TBARS), and nitric oxide $(\mathrm{NO})(15,16)$. Numerous studies reported that cisplatin has a potential to induce oxidative damage in heart tissue by causing peroxidation of the cell membrane and dysfunction of mitochondria $(17,18)$.

The present study was performed in order to assess the cardiotoxicity of cisplatin and its analogue, $\mathrm{Pt}^{(\mathrm{II})} \mathrm{DACHCl}$ (dichloro(1,2-diaminocyclohexane)platinum (II)), in isolated rat heart by means of oxidative stress markers in the coronary venous effluent.

\section{MATERIALS AND METHODS}

\section{Preparation of isolated rat hearts}

Male Wistar albino rats $(n=60,12$ per group, age 8 weeks, body mass 180-200 g) were killed by cervical dislocation (Schedule 1 of the Animals/Scientific procedures, Act 1986, UK) after short ether narcosis. After emergency thoracotomies and sudden arrest by superfusion with ice-cold physiological solution, the hearts were rapidly excised and perfused via the aorta according to Langendorff's technique at a constant coronary perfusion pressure of $70 \mathrm{~cm} \mathrm{H}_{2} \mathrm{O}$. The composition of Krebs-Henseleit solution was as follows (mmol/l): $\mathrm{NaCl}$ (118); $\mathrm{KCl}(4,7) ; \mathrm{CaCl}_{2} \times 2 \mathrm{H}_{2} \mathrm{O}(2,5) ; \mathrm{MgSO}_{4} \times 7 \mathrm{H}_{2} \mathrm{O}(1,7)$; $\mathrm{NaHCO}_{3}(25) ; \mathrm{KH}_{2} \mathrm{PO}_{4}(1,2)$; glucose $(5,5)$. The solution was balanced with $95 \% \mathrm{O}_{2}$ and $5 \% \mathrm{CO}_{2}$ at $37^{\circ} \mathrm{C}$, with a $\mathrm{pH}$ value of 7,4. Immediately after the establishment of automatic operation by opening the left atrium of the heart and dissecting the mitral valve, the sensor was inserted (transducer BS4 73-0184, Experimetria Ltd, Budapest, Hungary) into the left ventricle for continuous registration of myocardial function.

\section{Physiological assay and experimental protocol}

After the stabilization period of 30 minutes, the hearts were perfused with different concentrations (from $10^{-4}$ to $10^{-8} \mathrm{M}$ ) of following substances: $\mathrm{CDDP}, \mathrm{Pt}^{(\mathrm{II})} \mathrm{DACHCl}$, $\mathrm{K}_{2}\left[\mathrm{PtCl}_{4}\right], \mathrm{DACH}$ and Krebs-Henseleit solution (control group).

\section{Biochemical assays}

Samples of coronary venous effluent were collected at the end of the period of perfusion with each of the tested compounds (30, 60, 90, 120 minutes).

\section{Superoxide determination}

Superoxide anion radical $\left(\mathrm{O}_{2}{ }^{-}\right)$levels were measured in the coronary venous effluent by nitro blue tetrazolium (NBT) in TRIS buffer at a wavelength of $530 \mathrm{~nm}$. KrebsHenseleit solution was used as a blank probe (19).

\section{Hydrogen peroxide determination}

Hydrogen peroxide $\left(\mathrm{H}_{2} \mathrm{O}_{2}\right)$ levels were determined by measuring the oxidation of phenol red in a reaction catalysed by horseradish peroxidase (HRPO). The level of $\mathrm{H}_{2} \mathrm{O}_{2}$ was measured at $610 \mathrm{~nm}(20)$.

\section{Nitrite determination}

The nitrite level $\left(\mathrm{NO}_{2}^{-}\right)$was measured and used as an index of nitric oxide (NO) production using Griess's reagent. A total of $0,5 \mathrm{ml}$ of perfusate was precipitated with $200 \mu \mathrm{l}$ of $30 \%$ sulphosalicylic acid, vortexed for $30 \mathrm{~min}$ and centrifuged at $3000 \mathrm{~g}$. Equal volumes of the supernatant and Griess's reagent, containing 1\% sulphanilamide in 5\% phosphoric acid $/ 0,1 \%$ naphtalene ethylenediamine dihydrochloride, were added and incubated for $10 \mathrm{~min}$ in the dark and measured at $543 \mathrm{~nm}$. The nitrite levels were calculated using sodium nitrite as a standard (21).

\section{Determination of TBARS}

\section{(Index of lipid peroxidation)}

The degree of lipid peroxidation in the coronary venous effluent was estimated by TBARS (Thiobarbituric Acid Reactive Substances) using 1\% thiobarbituric acid (TBA) in 0,05 sodium hydroxide $(\mathrm{NaOH})$, incubated with coronary effluent at $100^{\circ} \mathrm{C}$ for 15 minutes and measured at $530 \mathrm{~nm}$. Krebs-Henseleit solution was used as a blank probe (22). 


\section{Substances}

$\mathrm{Pt}^{(\mathrm{II})} \mathrm{DACHCl}$, was synthesized according to Galanski and Keppler (23). Cisplatin, $\mathrm{K}_{2}\left[\mathrm{PtCl}_{4}\right]$, DACH and substances necessary for the preparation of Krebs-Henseleit buffer were purchased from the company Sigma-Aldrich GmbH, Germany.

\section{Statistical Analysis}

Experimental data were expressed as the arithmetic mean value $(\mathrm{X}) \pm$ standard deviation $(\mathrm{SD})$. Linear regression on logarithmically transformed data was used to determine the concentration-response relationship. This was calculated according to the method of least squares. The effect of different concentrations of experimental substances was expressed as a percentage of the maximal response. Analysis of variance was used to test significance of the linear regression with $\mathrm{p}$ values lower than 0.05 considered statistically significant. For all experimental substances, we calculated the $\mathrm{EC}_{50}$, the concentration eliciting $50 \%$ of the maximum response.

\section{RESULTS}

The results are summarized in Tables $1,2,3$, and 4 .

Under CDDP, $\mathrm{Pt}^{(\mathrm{II})} \mathrm{DACHCl} \mathrm{K}_{2}, \mathrm{~K}_{2}\left[\mathrm{PtCl}_{4}\right]$, and $\mathrm{DACH}$ perfusion of isolated rat heart (from $10^{-8}$ to $10^{-4} \mathrm{M}$ ), the levels of oxidative stress parameters $\left(\mathrm{O}_{2}^{-}, \mathrm{H}_{2} \mathrm{O}_{2}, \mathrm{NO}\right.$, and TBARS) were not affected significantly.

$\mathrm{O}_{2} \cdots$ CDDP: $F=1,02, d f_{1}=4, d f_{2}=25, \mathrm{p}>0,05 ; \mathrm{Pt}^{(\mathrm{II})}$ $\mathrm{DACHCl}_{2}: F=0,09, d f_{1}=4, d f_{2}=25, \mathrm{p}>0,05 ; \mathrm{K}_{2}\left[\mathrm{PtCl}_{4}\right]$ :

$F=0,73, d f_{1}=4, d f_{2}=25, \mathrm{p}>0,05 ; \mathrm{DACH}: F=0,87, d f_{1}=4$, $d f_{2}=25, \mathrm{p}>0,05$.

$\mathbf{H}_{2} \mathbf{O}_{2} \cdot$ CDDP: $F=0,81, d f_{1}=4, d f_{2}=25, \mathrm{p}>0,05 ; \mathrm{Pt}^{(\mathrm{II})}$ $\mathrm{DACHCl}_{2}: F=0,01, d f_{1}=4, d f_{2}=25, \mathrm{p}>0,05 ; \mathrm{K}_{2}\left[\mathrm{PtCl}_{4}\right]$ : $F=0,82, d f_{1}=4, d f_{2}=25, \mathrm{p}>0,05 ; \mathrm{DACH}: F=0,67 ; d f_{1}=4$, $d f_{2}=25, \mathrm{p}>0,05$;

NO. CDDP: $F=0,75, d f_{1}=4, d f_{2}=25, \mathrm{p}>0,05 ; \mathrm{Pt}^{(\mathrm{II})}$ $\mathrm{DACHCl}_{2}: F=0,06, d f_{1}=4, d f 2=25, \mathrm{p}>0,05 ; \mathrm{K}_{2}\left[\mathrm{PtCl}_{4}\right]$ : $F=1,19, d f_{1}=4, d f_{2}=25, \mathrm{p}>0,05 . \mathrm{DACH}: F=1,22, d f_{1}=4$, $d f_{2}=25, \mathrm{p}>0,05$.

TBARS. CDDP: $F=1,06, d f_{1}=4, d f_{2}=25, \mathrm{p}>0,05 ; \mathrm{Pt}^{(\mathrm{II})}$ $\mathrm{DACHCl}_{2}: F=0,1, d f_{1}=4, d f_{2}=25, \mathrm{p}>0,05 ; \mathrm{K}_{2}\left[\mathrm{PtCl}_{4}\right]: F=0,15$, $d f_{1}=4, d f_{2}=25, \mathrm{p}>0,05 ; \mathrm{DACH}: F=1,08 ; d f_{1}=4, d f_{2}=25$, $\mathrm{p}>0,05$.

\section{DISCUSSION}

The mechanisms of the anticancer effects of cisplatin are relatively well-known, but the cellular and molecular mechanisms involved in its cardiotoxicity are still not clear (24). Cardiotoxicity is a severe side effect that can occur during cisplatin treatment and is a limiting factor of cisplatin use in chemotherapy $(25,26)$. The best studied antitumour drugs with cardiotoxic effects are anthracyclines; however, in recent years, much attention has been paid to the mechanisms of cisplatin-induced cardiotoxicity. Many preclinical and clinical studies indicate that the use of anthracyclines is associated with myocardial damage, which is initiated by the formation of oxidative free radicals. Sawyer et al. (27) showed that apoptotic cells could be found in rat cardiomyocytes upon exposure to doxorubicin. Additionally, several investigations have shown the role of mitochondrial damage in a few models of nephroand ototoxicity induced after cisplatin administration (28, 29). Mitochondria have a central role in myocardial tissue homeostasis, since cardiomyocytes are cells with high energy metabolism. Cardiac myocytes can accumulate a large amount of cisplatin and establish enhanced mtDNA damage. Thus, impairment in mitochondrial function leads to apoptosis of myocytes and endothelial cells and consequent cardiac dysfunction. Mitochondrial dysfunction can develop via various mechanisms, such as the loss of mitochondrial membrane potential, depletion of mitochondrial antioxidant enzymes, and increase in oxidative and nitrosative stress, which can induce cell death (30). The increase of oxidative stress and apoptosis in rat liver after cisplatin treatment (31) and overproduction of ROS in rat heart tissue (32) may lead to cardiovascular complications.

Hence, excessive production of ROS (superoxide anion radical, hydrogen peroxide, thiobarbituric reactive substances, and nitric oxide), in addition to the impairment of the defence system of antioxidant enzymes (superoxide dismutase, catalase, and glutathione peroxidase), contributes to oxidative stress damage of the heart tissue (33). The levels of antioxidants, such as glutathione (GSH), are decreased significantly during cisplatin therapy with a high cumulative dose (34).

Cisplatin causes severe cardiotoxic effects that can impair the quality of life thus a $\mathrm{Pt}(\mathrm{II}) \mathrm{DACHCl} 2$ complex was synthesized and tested for cardiotoxicity in the isolated rat heart. Platinum (II) complexes with 1,2-diaminocyclohexane $(\mathrm{DACH})$ as a ligand display high cytotoxic activity in tumours with a primary resistance to cisplatin, as well as lower nephro- and myelotoxicity (35). Success of oxaliplatin, which incorporates the $1 \mathrm{R}, 2 \mathrm{R}-\mathrm{DACH}$ ligand as platinum (II) complex, raised research interest over the past few decades for platinum-DACH complexes. Platinum (II) analogues have a strong potential for binding to sulphur donor groups, such as glutathione and metallothioneins. Consequently, before this complex reaches the DNA of the cancer cells, it can interact with many compounds, resulting in its inactivation and side effects (26).

In our study, isolated rat hearts were perfused with two platinum complexes in divergent concentrations as follows: $10^{-8}, 10^{-7}, 10^{-6}, 10^{-5}, 10^{-4} \mathrm{M}$. The obtained results revealed that administration of cisplatin and $\mathrm{Pt}^{(\mathrm{II})} \mathrm{DACHCl}_{2}$ induced production of $\mathrm{O}_{2}^{--}$(Table 1) similar to when applied in a lower concentration range $\left(10^{-8}-10^{-6} \mathrm{M}\right)$, whereas at high- 
Table 1.The effects of CDDP, $\mathrm{Pt}^{(\mathrm{II})} \mathrm{DACHCl} \mathrm{DACH}_{2}$, $\mathrm{K}_{2} \mathrm{PtCl}_{4}$ perfusion on $\mathrm{O}_{2}$.

\begin{tabular}{|c|c|c|c|c|c|}
\hline \multirow{2}{*}{$\mathrm{n}=12$} & \multicolumn{5}{|c|}{$X \pm S D\left(\mathrm{nmol} \mathrm{min}{ }^{-1} \mathrm{~g}^{-1}\right)$} \\
\hline & Control & Cisplatin & $\mathbf{P t}^{(\mathrm{II})} \mathrm{DACHCl}{ }_{2}$ & DACH & $\mathrm{K}_{2} \mathrm{PtCl}_{4}$ \\
\hline $10^{-8}$ & $55,72 \pm 18,09$ & $23,80 \pm 14,61$ & $30,46 \pm 26,89$ & $38,54 \pm 25,64$ & $36,40 \pm 22,90$ \\
\hline $10^{-7}$ & $73,52 \pm 40,52$ & $43,96 \pm 22,35$ & $37,05 \pm 43,37$ & $19,65 \pm 12,54$ & $29,16 \pm 18,95$ \\
\hline $10^{-6}$ & $45,04 \pm 26,20$ & $27,93 \pm 26,95$ & $29,73 \pm 15,86$ & $18,20 \pm 13,27$ & $52,90 \pm 47,37$ \\
\hline $10^{-5}$ & $70,17 \pm 42,31$ & $14,36 \pm 8,84$ & $65,30 \pm 94,53$ & $14,82 \pm 5,14$ & $21,47 \pm 15,83$ \\
\hline $10^{-4}$ & $49,87 \pm 15,36$ & $13,14 \pm 12,36$ & $46,80 \pm 40,59$ & $8,50 \pm 4,28$ & $8,95 \pm 5,16$ \\
\hline
\end{tabular}

Table 2.The effects of CDDP, $\mathrm{Pt}^{(\mathrm{II})} \mathrm{DACHCl}{ }_{2,} \mathrm{DACH}, \mathrm{K}_{2} \mathrm{PtCl}_{4}$ perfusion on $\mathrm{H}_{2} \mathrm{O}_{2}$

\begin{tabular}{|c|c|c|c|c|c|}
\hline \multirow{2}{*}{$\mathrm{n}=12$} & \multicolumn{5}{|c|}{$X \pm S D\left(\mathrm{nmol} \min ^{-1} \mathbf{g}^{-1}\right)$} \\
\hline & Control & Cisplatin & $\mathbf{P t}^{(\mathrm{II})} \mathrm{DACHCl} \mathrm{I}_{2}$ & DACH & $\mathrm{K}_{2} \mathrm{PtCl}_{4}$ \\
\hline $10^{-8}$ & $23,54 \pm 13,26$ & $13,61 \pm 4,33$ & $17,54 \pm 5,89$ & $24,47 \pm 10,02$ & $2,97 \pm 2,74$ \\
\hline $10^{-7}$ & $18,58 \pm 5,43$ & $11,90 \pm 6,50$ & $18,49 \pm 7,85$ & $18,71 \pm 4,48$ & $1,40 \pm 1,25$ \\
\hline $10^{-6}$ & $19,67 \pm 7,48$ & $9,28 \pm 5,03$ & $18,11 \pm 6,51$ & $17,35 \pm 2,82$ & $1,08 \pm 0,53$ \\
\hline $10^{-5}$ & $17,30 \pm 10,94$ & $8,95 \pm 5,30$ & $20,94 \pm 7,42$ & $11,74 \pm 3,00$ & $0,55 \pm 0,51$ \\
\hline $10^{-4}$ & $20,01 \pm 14,97$ & $4,47 \pm 2,96$ & $13,93 \pm 4,83$ & $3,98 \pm 1,13$ & $0,26 \pm 0,20$ \\
\hline
\end{tabular}

Table 3.The effects of CDDP, $\mathrm{Pt}^{(\mathrm{II})} \mathrm{DACHCl}{ }_{2}, \mathrm{DACH}, \mathrm{K}_{2} \mathrm{PtCl}_{4}$ perfusion on $\mathrm{NO}$

\begin{tabular}{|c|c|c|c|c|c|}
\hline \multirow{2}{*}{$\mathrm{n}=12$} & \multicolumn{5}{|c|}{$X \pm S D\left(\right.$ nmol $\left.\min ^{-1} \mathbf{g}^{-1}\right)$} \\
\hline & Control & Cisplatin & $\mathrm{Pt}^{(\mathrm{II})} \mathrm{DACHCl}_{2}$ & DACH & $\mathrm{K}_{2} \mathrm{PtCl}_{4}$ \\
\hline $10^{-8}$ & $5,20 \pm 4,39$ & $10,24 \pm 4,79$ & $9,55 \pm 6,21$ & $6,69 \pm 2,53$ & $12,19 \pm 3,96$ \\
\hline $10^{-7}$ & $3,72 \pm 2,40$ & $10,60 \pm 4,20$ & $10,44 \pm 6,70$ & $4,09 \pm 2,30$ & $8,90 \pm 3,90$ \\
\hline $10^{-6}$ & $2,35 \pm 1,94$ & $8,99 \pm 2,22$ & $5,76 \pm 3,12$ & $3,94 \pm 1,34$ & $7,58 \pm 1,12$ \\
\hline $10^{-5}$ & $2,80 \pm 1,33$ & $6,29 \pm 4,16$ & $7,57 \pm 6,86$ & $3,18 \pm 2,13$ & $3,81 \pm 0,62$ \\
\hline $10^{-4}$ & $2,05 \pm 1,46$ & $3,12 \pm 0,85$ & $5,00 \pm 2,80$ & $1,97 \pm 1,92$ & $1,60 \pm 0,82$ \\
\hline
\end{tabular}

Table 4. The effects of CDDP, $\mathrm{Pt}^{(\mathrm{II})} \mathrm{DACHCl} \mathrm{DACH}_{2}, \mathrm{~K}_{2} \mathrm{PtCl}_{4}$ perfusion on TBARS

\begin{tabular}{|c|c|c|c|c|c|}
\hline \multirow{2}{*}{$\mathrm{n}=12$} & \multicolumn{5}{|c|}{$X \pm S D\left(\mu \mathrm{mol} \mathrm{min} \mathrm{min}^{-1} \mathrm{~g}^{-1}\right)$} \\
\hline & Control & Cisplatin & $\mathrm{Pt}^{(\mathrm{II})} \mathrm{DACHCl}_{2}$ & DACH & $\mathrm{K}_{2} \mathrm{PtCl}_{4}$ \\
\hline $10^{-8}$ & $14,72 \pm 9,91$ & $28,68 \pm 23,76$ & $23,96 \pm 15,19$ & $29,01 \pm 12,59$ & $40,04 \pm 18,38$ \\
\hline $10^{-7}$ & $11,73 \pm 10,26$ & $20,65 \pm 16,24$ & $22,42 \pm 18,58$ & $35,69 \pm 17,36$ & $48,84 \pm 18,59$ \\
\hline $10^{-6}$ & $14,95 \pm 10,50$ & $24,56 \pm 11,41$ & $17,45 \pm 12,55$ & $31,37 \pm 25,78$ & $37,10 \pm 22,36$ \\
\hline $10^{-5}$ & $12,58 \pm 9,23$ & $15,97 \pm 10,15$ & $14,57 \pm 14,41$ & $23,63 \pm 12,71$ & $18,35 \pm 6,52$ \\
\hline $10^{-4}$ & $13,56 \pm 8,10$ & $8,49 \pm 4,60$ & $17,92 \pm 28,18$ & $5,50 \pm 2,58$ & $7,03 \pm 4,39$ \\
\hline
\end{tabular}


er concentrations $\left(10^{-5}-10^{-4} \mathrm{M}\right)$, the $\mathrm{Pt}^{(\mathrm{II})} \mathrm{DACHCl}_{2}$ complex induced significant elevation of $\mathrm{O}_{2}^{-}$in comparison with CDDP.

Table 1.The effects of CDDP, $\mathrm{Pt}^{(\mathrm{II})} \mathrm{DACHCl} \mathrm{DACH}_{2} \mathrm{D}$ $\mathrm{K}_{2} \mathrm{PtCl}_{4}$ perfusion on $\mathrm{O}_{2}$

Cisplatin applied in a lower concentration range can induce apoptosis via the overproduction of free radicals in renal tubular cells (36), whereas higher concentrations induce necrosis via $\mathrm{O}_{2}^{--}$and $\mathrm{H}_{2} \mathrm{O}_{2}$. This result indicates that cardiotoxicity may occur in a dose-dependent manner.

The data obtained in our study showed that the $\mathrm{Pt}^{(\mathrm{II})}$ $\mathrm{DACHCl}_{2}$ complex induced higher levels of hydrogen peroxide production (Table 2 ) through the whole range of applied doses $\left(10^{-8}-10^{-4} \mathrm{M}\right)$, which is in contrast to the CDDP results.

Table 2.The effects of CDDP, $\mathrm{Pt}^{(\mathrm{II})} \mathrm{DACHCl}_{2}, \mathrm{DACH}$, $\mathrm{K}_{2} \mathrm{PtCl}_{4}$ perfusion on $\mathrm{H}_{2} \mathrm{O}_{2}$

Numerous effects of oxidative stress are observed in many diseases and are also implicated in the toxicity induced by anticancer agents such as cisplatin. There is in vivo and in vitro evidence that cisplatin induces oxidative stress, which is involved in renal damage and severe nephrotoxicity. This is confirmed by the increasing levels of $\mathrm{O}_{2}^{-}$, $\mathrm{H}_{2} \mathrm{O}_{2}$ and hydroxyl radicals, as well as by the depletion of the antioxidants GSH-peroxidase and GSH-reductase (17).

The present study determined the nitrite level $\left(\mathrm{NO}_{2}^{-}\right)$ as an index of nitric oxide (NO) production (Table 3). It was shown that formation of NO is higher at lower doses of each complex $\left(10^{-8}-10^{-7} \mathrm{M}\right)$ and is lower at higher doses $\left(10^{-6}-10^{-4} \mathrm{M}\right)$.

Table 3.The effects of CDDP, $\mathrm{Pt}^{(\mathrm{II})} \mathrm{DACHCl}_{2} \mathrm{DACH}$, $\mathrm{K}_{2} \mathrm{PtCl}_{4}$ perfusion on $\mathrm{NO}$

Demkow and coauthors (37) observed a significant increase of NO production in lung cancer patients after cisplatin administration. In the presence of a superoxide anion radical, nitric oxide forms peroxynitrite, which is more reactive and toxic, and has a potential for apoptosis of cells such as cardiomyocytes (38). In accordance with these results, Zhou et al. (39) reported significant elevation of serum NO after chemotherapy in patients with lung cancer. Chirino et al. (17) also showed that high production of peroxynitrite plays a role in the pathogenesis of nephrotoxicity after cisplatin application. Peroxynitrite can induce cell damage by developing lipid peroxidation, causing DNA damage and mitochondrial dysfunction. In contrast, Colakogullari and coworkers (40) did not observe high concentrations of $\mathrm{NO}$ as an early effect of cisplatin therapy. This variation can be attributed to different study protocols.

In our research, TBARS was measured as an index of lipid peroxidation, and it is observed that levels of lipid peroxidation were higher at lower doses of cisplatin $\left(10^{-8}\right.$ $10^{-6} \mathrm{M}$ ) in comparison with $\mathrm{Pt}^{(\mathrm{II})} \mathrm{DACHCl}_{2}$ (Table 4).
Table 4.The effects of CDDP, $\mathrm{Pt}^{(\mathrm{II})} \mathrm{DACHCl}_{2}, \mathrm{DACH}$, $\mathrm{K}_{2} \mathrm{PtCl}_{4}$ perfusion on TBARS

However, the $\mathrm{Pt}^{(\mathrm{II})} \mathrm{DACHCl} \mathrm{HCl}_{2}$ complex caused an increase in the levels of lipid peroxidation when applied at the highest dose $\left(10^{-4} \mathrm{M}\right)$, which is in contrast to cisplatin. Cardiotoxicity associated with cisplatin therapy could also be the consequence of increased lipid peroxidation in myocardial cells that resulted in irreversible modification of cell functions. Free radicals can cause serious damage to tissue, reacting with membrane lipids, proteins and nucleic acids (41). After cisplatin is distributed to a cell, it is aquated into a highly reactive form, which can react with GSH and metallothioneins. Depletion of GSH levels and antioxidants results in the accumulation of $\operatorname{ROS}(42,43)$.

The current study compared the $\mathrm{Pt}^{(\mathrm{II})} \mathrm{DACHCl} \mathrm{HCO}_{2}$ plex to CDDP for their ability to develop cardiotoxicity by the production of free radicals. Over the complete dosage range tested, neither complex produced a statistically significant elevation of ROS or induced evidently cardiotoxic effects. Data presented in this research could be useful for future investigations of platinum-based chemotherapeutic agents. These results suggest that further elucidation of platinum (II) analogue-induced cardiotoxicity should add significantly to our understanding of this phenomenon and the role of platinum complexes with DACH ligands in anticancer treatment.

\section{REFERENCES}

1. Bruijnincx PC, Sadler PJ. New trends for metal complexes with anticancer activity. Curr Opin Chem Biol 2008; 12(2): 197-206.

2. van Rijt SH, Sadler PJ. Current applications and future potential for bioinorganic chemistry in the development of anticancer drugs. Drug Discov Today 2009; 14(23-24): 1089-97, DOI: 10.1016/j.drudis.2009.09.003.

3. Oun R, Wheate NJ. Platinum Anticancer Drugs. In: Kretsinger RH, Uversky VN, Permiyakov EA: Encyclopedia of Metalloproteins. New York, Heidelberg, Dordrecht, London: Springer 2013: pp.1710-14.

4. Cepeda V, Fuertes MA, Castilla J, Alonso C, Quevedo C, Peres JM. Biochemical Mechanisms of Cisplatin Cytotoxicity. Anticancer Agents Med Chem 2007; 7(1): 3-18.

5. Weijl NI, Hopman GD, Wipkink-Bakker A, Lentjes EG, Berger HM, Cleton FJ, Osanto S. Cisplatin combination chemotherapy induces a fall in plasma antioxidants of cancer patients. Ann Oncol 1998; 9(12): 1331-7.

6. Jung Y, Lippard SJ. Direct cellular responses to platinum induced DNA damage. Chem Rev 2007; 107: 1387-1407.

7. Rabik CA, Dolan ME. Molecular mechanisms of resistance and toxicity associated with platinating agents. Cancer Treat Rev 2007; 33(1): 9-23. 
8. van Zutphen S, Reedijk J. Targeting platinum anti-tumour drugs: overview of strategies employed to reduce systemic toxicity. Coord Chem Rev 2005; 249: 2845-53.

9. Barry NP, Sadler PJ. Exploration of the medical periodic table: towards new targets. Chem Commun (Camb) 2013; 49: 5106-31.

10. Pai V, Nahata M. Cardiotoxicity of chemotherapeutic agents: incidence, treatment and prevention. Drug Saf 2000; 22(4): 263-302.

11. Patanè S. Cardiotoxicity: cisplatin and long-term cancer survivors. Int J Cardiol 2014; 175(1): 201-2.

12. Al-Majed AA, Sayed-Ahmed MM, Al-Yahya AA, Aleisa AM, Al-Rejaie SS, Al- Shabanah OA. Propionyl-Lcarnitine prevents the progression of cisplatin-induced cardiomyopathy in a carnitine-depleted rat model. Pharmacol Res 2006; 53(3): 278-86.

13. Meinardi MT, Gietema JA, van der Graaf WT, van Veldhuisen DJ, Runne MA, Sluiter WJ et al. Cardiovascular morbidity in long term survivors of metastatic testicular cancer. J Clin Oncol 2000; 18: 172532.

14. Kucharz J, Michalowska-Kaczmarczyk A, Zygulska A, Wojtak J et al. Bradycardia as a rare symptom of cisplatin cardiotoxicity: a case report. Oncol Lett 2016; 11(3): 2297-99.

15. Albini A, Pennesi G, Donatelli F, Cammarota R, De Flora S, Noonan DM. Cardiotoxicity of anticancer drugs: The need for Cardio-Oncology and Cardio-Oncological Prevention. J Natl Cancer Inst 2010; 102:14-25.

16. Minotti G, Salvatorelli E, Menna P. Pharmacological foundations of cardio-oncology. J Pharmacol Exp Ther 2010; 334: 2-8.

17. Chirino YI, Pedraza-Chaverri J. Role of oxidative and nitrosative stress in cisplatin-induced nephrotoxicity. Exp Toxicol Pathol 2009; 61(3): 223-42.

18. Hussein A, Ahmed AA, Shouman SA, Sharawy S. Ameliorating effect of DL-a-lipoic acid against cisplatin-induced nephrotoxicity and cardiotoxicity in experimental animals. Drug Discov Ther 2012; 6(3): 147-56.

19. Auclair C, Voisin E. Nitroblue tetrazolium reduction. In: Greenvvald RA (Ed.): Handbook of methods for oxygen radical research. CRC Press, Boca Raton $1985 ; 123-32$.

20. Pick E, Keisari Y. A simple colorimetric method for the measurement of hydrogen peroxide produced by cells in culture. J Immunol Methods 1980; 38: 161-70.

21. Green LC, Wagner DA, Glogowski J, Skipper PL, Wishnok JS, Tannenbaum SR. Analysis of nitrate, nitrite and [15N] nitrate in biological fluids. Anal Biochem 1982; 126(1): 131-8.

22. Ohkawa H, Ohishi N, Yagi K. Assay for lipid peroxides in animal tissues by thiobarbituric acid reaction. Anal Biochem 1979; 95(2): 351-8.

23. Galanski M, Keppler BK. Synthesis and characterization of new ethylendiamine platinum (IV) complexes containing lipophilic carboxylate ligands. Metal Based Drugs 1995; 2: 57-63.
24. Ma H, Jones KR, Guo R, Xu P, Shen Y, Ren J. Cisplatin compromises myocardial contractile function and mitochondrial ultrastructure: role of endoplasmic reticulum stress. Clin Exp Pharmacol Physiol 2010; 37: 460-5.

25. Ferroni P, Della-Morte D, Palmirotta R, McClendon M, Testa G, Abete P et al. Platinum-based compounds and risk for cardiovascular toxicity in elderly: role of the antioxidants in chemoprevention. Rejuvenation Res 2011; 14: 293-308.

26. El-Awady ES, Moustafa YM, Abo-Elmatty DM, Radwan A. Cisplatin-induced cardiotoxicity: mechanisms and cardioprotective strategies. Eur J Pharmacol 2011; 650: 335-41.

27. Sawyer DB, Fukazawa R, Arstall MA, Kelly RA. Daunorubicin-induced apoptosis in rat cardiac myocytes is inhibited by dexrazoxane. Circ Res 1999; 84: 257-65.

28. Park MS, De Leon M, Devarajan P. Cisplatin induces apoptosis in LLC-PK1 cells via activation of mitochondrial pathways. J Am Soc Nephrol 2002; 13: 858-65.

29. Devarajan P, Savoca M, Castaneda MP, Park MS, Esteban-Cruciani N, Kalinec G et al. Cisplatin-induced apoptosis in auditory cells: role of death receptor and mitochondrial pathways. Heart Res 2002; 17: 45-54.

30. Varga ZV, Ferdinandy P, Liaudet L, Pacher P. Drug-induced mitochondrial dysfunction and cardiotoxicity. Am J Physiol Heart Circ Physiol 2015; 309(9): H1453-67.

31. Martins NM, Santos NA, Curti C, Bianchi ML, Santos AC. Cisplatin induces mitochondrial oxidative stress with resultant energetic metabolism impairment, membrane rigidification and apoptosis in rat liver. J Appl Toxicol 2008; 28(3): 337-44.

32. Yuce A, Atessahin A, Ceribasi AO, Aksakal M. Ellagic acid prevents cisplatin-induced oxidative stress in liver and heart tissue of rats. Basic Clin Pharmacol Toxicol 2007; 101(5): 345-9.

33. Halliwell B. Reactive species and antioxidants. Redox biology is a fundamental theme of aerobic life. Plant Physiol 2006; 141: 312-22.

34. Nakhaee A, Bokaeian M, Noori S, Mahboob T. Antioxidant effect of carnosine pretreatment on cisplatininduced renal oxidative stress in rats.Indian J Clin Biochem 2010; 25: 86-91.

35. Jakupec MA, Galanski M, Keppler BK. Tumour-inhibiting platinum complexes-state of the art and future perspectives. Rev Physiol Biochem Pharmacol 2003; 146: 1-53.

36. Baek SM, Kwon CH, Kim JH, Woo Js, Jung JS, Kim YK. Differential roles of hydrogen peroxide and hydroxyl radical in cisplatin-induced cell death in renal proximal tubular epithelial cells. J Lab Clin Med 2003; 142(3): 178-86.

37. Demkow U, Stelmaszczyk-Emmel A. Cardiotoxicity of cisplatin-based chemotherapy in advanced non-small cell lung cancer patients. Respir Physiol Neurobiol 2013; 187:64-7.

38. Crohns M, Liippo K, Erhola M, Kankaanranta H, Moilanen E, Alho $\mathrm{H}$ et al. Concurrent decline of sev- 
eral antioxidants and markers of oxidative stress during combination chemotherapy for small cell lung cancer. Clinical Biochemistry 2009; 42: 1236-45.

39. Zhou J, Zhu Q, Yao H. Chemotherapy of non-small-cell lung cancer (NSCLC) and changes in serum sAPO-1/Fas and nitric oxide (NO) levels. Chin J Onc 2000; 22: 225-7.

40. Colakogullari M, Ulukaya E, Yilmaztepe A, Ocakoglu G, Yilmaz M, Karadag M et al. Higher serum nitrate levels are associated with poor survival in lung cancer patients. Clinical Biochemistry 2006; 39: 898-903.
41. Conklin KA, Nicolson GL. Molecular replacement in cancer therapy: reversing cancer metabolic and mitochondrial dysfunction, fatigue and the adverse effects of cancer therapy. Curr Cancer Ther Rev 2008; 4: 66-76.

42. Deavall DG, Martin EA, Horner JM, Roberts R. Druginduced oxidative stress and toxicity. J Toxicol. 2012; 645460 DOI: $10.1155 / 2012 / 645460$.

43. Dasari S, Tchounwou PB. Cisplatin in cancer therapy: Molecular mechanisms of action. Eur J Pharmacol 2014; 740: 364-78. 